\title{
Study of biological and molecular characterization of pepper-PVY isolated from Tehran pepper fields and it's comparison with other PVY isolates
}

\author{
Mostafae S. ${ }^{*}{ }^{1}$, Mosahebi G. ${ }^{1}$, Koohi Habibi M. ${ }^{1}$, Ansari.Dezfouli E. ${ }^{2}$ \\ 1: College of agriculture and Natural Resources Faculty of Horticulture Sciences \\ and Plant Protection, University of Tehran \\ 2: College of Agriculture, Faculty of Biotechnology, University of Kerman
}

\begin{abstract}
Potato virus $Y$ a type species of the genus potyvirus infects several crops in the family solanaceae. PVY isolated from field infected peppers was identified on the basis of host reaction, serological and molecular characterization. The result of ELISA, Immunoblot electrophoresis and Immuno Capture Reverse Transcription Polymerase Chain Reaction (ICRT-PCR) indicated that pepper isolate of PVY shares the reported properties of the PVY but in host range studies some differences were observed. For this reason the sequence analysis was performed.This is the first report of PVY incidence in Iran pepper fields.
\end{abstract}

Keywords: Potato virus $Y$ GIC-RT-PCR GImmuno blot electrophoresis

\section{Introduction}

$\mathrm{P}$ otato Virus Y (PVY)is the type member of the genus potyvirus in the family potyviridae (9) and it has a single positive sense genomic RNA about $10 \mathrm{~Kb}$ long, inside flexuous virions.

PVY is the cause of major diseases in solanaceous crops including potato, tobacco, pepper, tomato and also infects many non solanaceous weeds. the symptoms induced by PVY and its host range are highly variable. These traits are used for the classification of PVY strains. PVY isolates have been historically classified according to symptomatology and aphid transmiss-ibility in to $\mathrm{PVY}^{\mathrm{O}}, \mathrm{PVY}^{\mathrm{N}}$ and $\mathrm{PVY}^{\mathrm{C}}$ groups (3), but recently, a host indep-endent classification ,based on RFLP pattern of the coat protein $(\mathrm{CP})$ gene after IC-RTPCR has been developed (7), allowing the regrouping of PVY isolates in three main clusters: potato $\mathrm{PVY}^{\mathrm{N}}$, potato $\mathrm{PVY}^{\mathrm{O}}$ and non potato $\mathrm{PVY}{ }^{\mathrm{NP}}$. In this paper, we present a biological and molecular chararacter-ization of typical pepper isolate of PVY especially in compa-rison with other PVY isolates.

\footnotetext{
${ }^{*}$ Corresponding Author: Somaye Mostfae, (o21) 44580438

email: saghar_200059@yahoo.com
}

\section{Material and methods}

359 Leaf samples with veinal necrosis, veinal clearing, mosaic and dwarfing symptoms were collected from 12 pepper farms in Tehran province during 2005 and 2006. Pepper leaf samples were tested for the presence of PVY. The double antibody sandwich ELISA was performed as previously described (2)using polyclonal antibody (DSMZ, AS-0137/403). ELISA plates (Nunc Maxisorb), coated with 1:1000 dilution of related IgG in carbonate coating buffer (15 Mm Na2co3, $35 \mathrm{Mm} \mathrm{NaHCO} 3$, and $5 \mathrm{Mm} \mathrm{NaN3}, \mathrm{PH}$ 9.6) and incubated overnight at $4 \mathrm{c}$. Samples were extracted with extraction buffer $(1: 5 \mathrm{wt} / \mathrm{vol}, 3 \mathrm{mM} \mathrm{KCL}$, 3Mm nan3, $8 \mathrm{Mm}$ Na2HPO4, $1 \mathrm{Mm}$ NaH2PO4, and $0.13 \mathrm{M}$ NaCL (PBS) containing 2\% polyvinilpyrolidone (PVP)-24000 and $0.05 \%$ Tween 20, Ph 7.4). Wells were washed four times, at 5-min intervals, with washing buffer $(0.05 \%$ Tween 20 in PBS), and $100 \mu 1$ of plant extract was . added to each well and incubated overnight at $4{ }^{\circ} \mathrm{c}$ Wells were washed four times with washing buffer; then $100 \mu \mathrm{l}$ of alkaline phosphatase conjugated IgG diluted in conjugate buffer (2\% PVP-24000, 0.05\% Tween 20, 0.2\% bovin serum albumin (BSA) and 1 $\mathrm{Mm} \mathrm{MgCL2}$ in PBS, Ph 7.40) was added and incubated $3 \mathrm{~h}$ at $37^{\circ} \mathrm{c}$. Wells were washed four times with washing buffer and incubated in $100 \mu \mathrm{l}$ of 


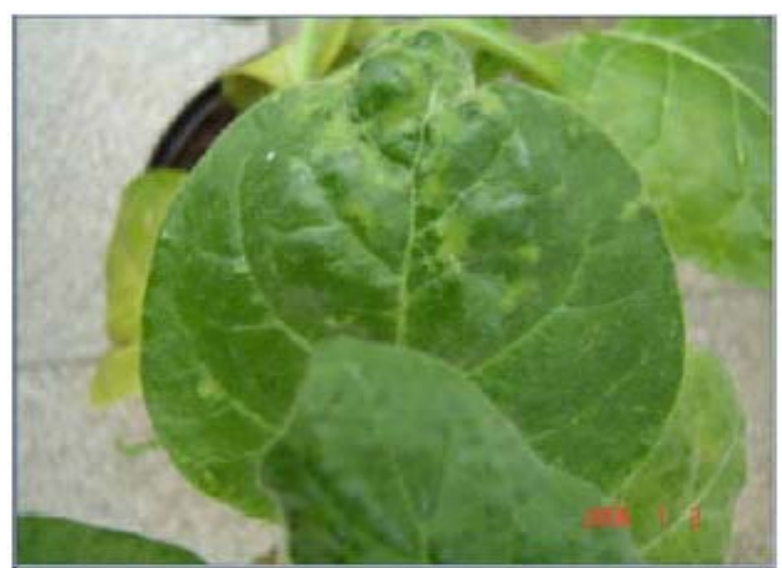

Fig. 2: Mosaic on N.rustica

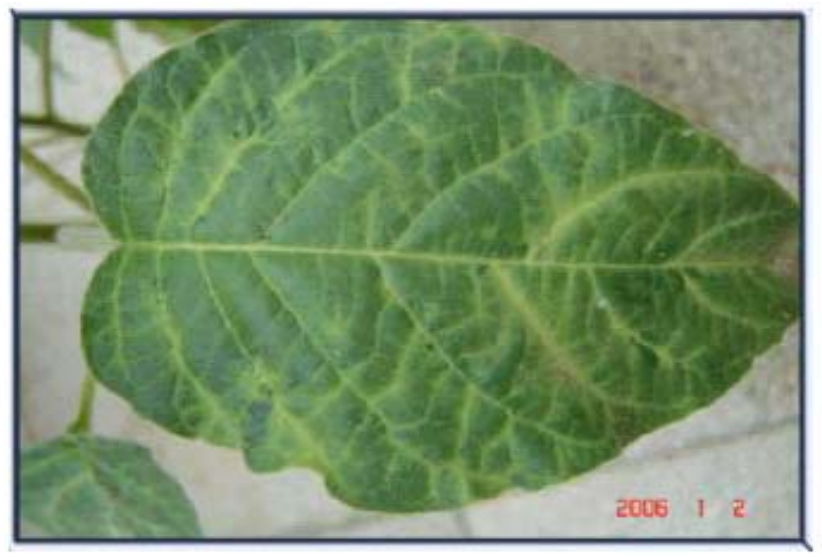

Fig. 4: Vein clearing and mosaic on Datura metal

substrate buffer $(1 \mathrm{mg} / \mathrm{ml} p$-nitrophenyl phosphate and $3 \mathrm{Mm} \mathrm{NaN3}$ in diethanolamin buffer, $\mathrm{Ph} 9.8$ ), absorbance was determined at $405 \mathrm{~nm}$ by an ELISA-reader after $30 \mathrm{~min}$. Samples with absorbance values greater than or equal to three times the average of negative samples were considered infected (positive).

Due to PVY-pepper host rang (A. Fanigliulo et al., 2005), the PVY-pepper isolate was mechanically inoculated on Nicotiana tabacum cv. White Burley, Nicotiana glutinosa, Chenopodium amaranticolor, Cheno-podium quinoa, Datura stramonium, Datura metel, Physalis floridana, Capsicum annuum and Solanum tuber-osum with phosphate buffer $(0.1 \mathrm{M}$, PH:7).

PVY isolated was propagated and mainted in N.tabacum cv.White Burley. After various passages in this host symptoms were observed and the purification was done using the method described by Leiser and Richter (1978) with some modifications. Homogen-ized 100 gr leaf tissue in $200 \mathrm{ml} 0.5 \mathrm{M}$ sodium citrate buffer, PH7.4, containing $5 \mathrm{mM}$ EDTA and $15 \mathrm{mM}$ sodium

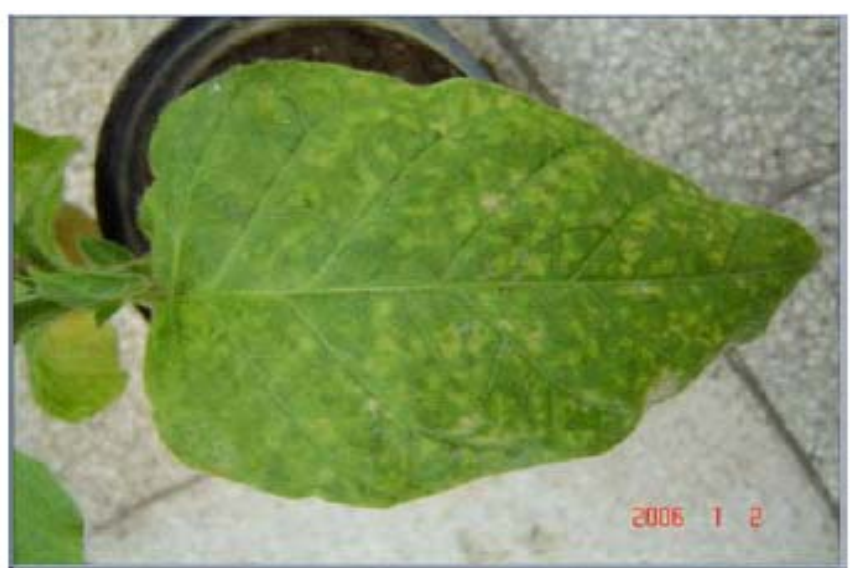

Fig. 1: Mosaic on N.tabacum CV.White Burley

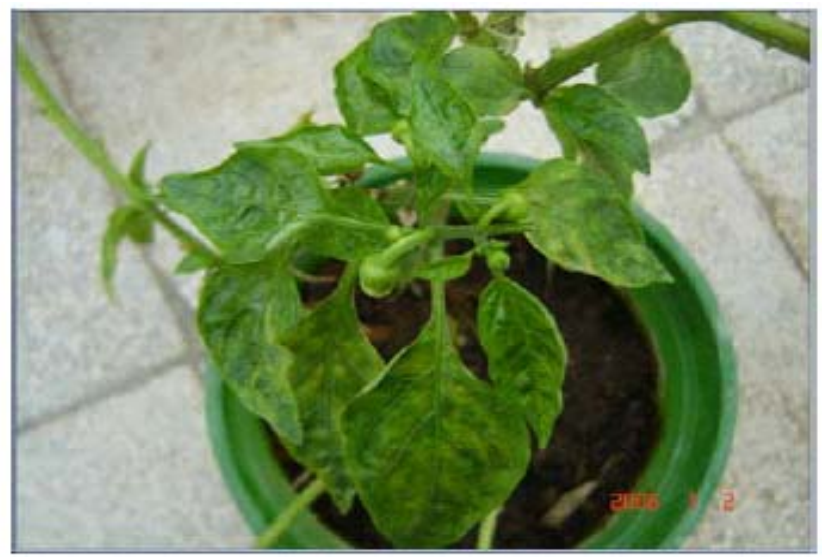

Fig. 3: vein clearing and yellowing on C.- annuum

DIECA. squeezed the homogenate through cheesecloth and centrifiuged for $15 \mathrm{~min}$ at 6000 $\mathrm{rev} / \mathrm{min}$. added triton $\mathrm{x}-100$ to a final concentration of $3 \%(\mathrm{v} / \mathrm{v})$ and stired for $30 \mathrm{~min}$ at 4 C.centrifuged for $2 \mathrm{~h}$ at $30,000 \mathrm{~g}$. Resuspended the pellets in $10 \mathrm{mM}$ sodium citrate buffer,PH7.4, containing $1 \mathrm{M}$ urea and $0.1 \%(\mathrm{v} / \mathrm{v})$ 2-mercaptoethanol. Centrifuged for $15 \mathrm{~min}$ at $15,000 \mathrm{rev} / \mathrm{min}$.layer the supernatant fluided over a cushion of $20 \%(\mathrm{w} / \mathrm{v})$ sucrose and centrifuged for $2 \mathrm{~h}$ at $50,000 \mathrm{~g}$. resuspend the pellets in $5 \mathrm{mM}$ borate buffer PH8, in $30 \mathrm{mM}$ Nacl, $3 \mathrm{mM}$ sodium citrate.

Two primers (NIa/F, NIa/R) previously described (4) were used as a control to amplify PVY strain groups. Another primers pairs were selected to specifically amplify $\mathrm{PVY}^{\mathrm{N}}, \mathrm{PVY}^{\mathrm{O}}, \mathrm{PVY}^{\mathrm{C}}$ and $\mathrm{PVY}^{\mathrm{NTN}}$ strains (1).

The nucleotide sequences of the coding region of PCR product of PVY was determined and was analyzed by multiple alignment with Blast Software to other isolates that were available in the Gen Bank. 


\section{Mostafae et al}

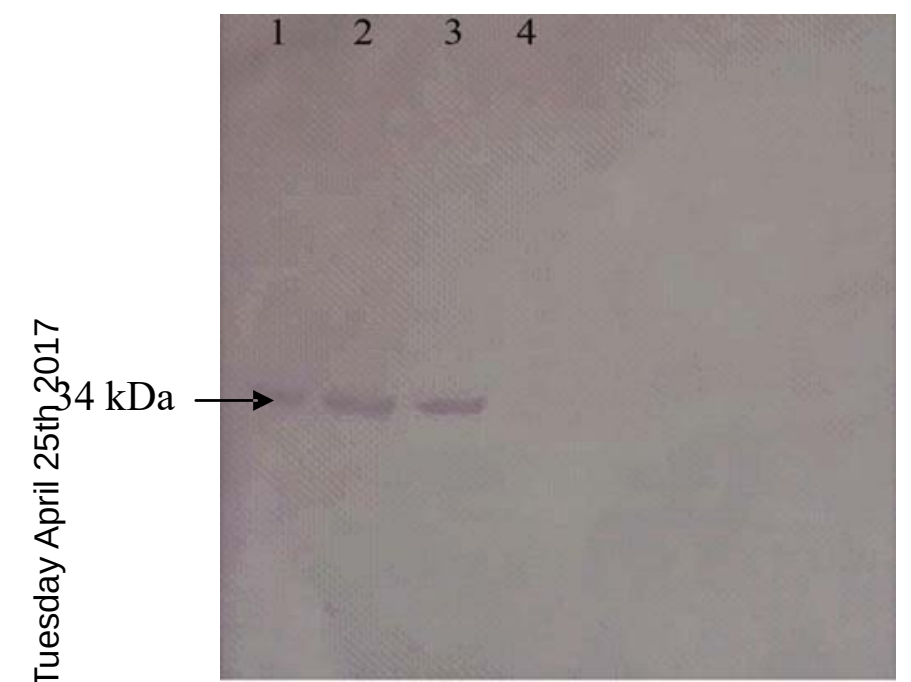

Fig. 6: western blotting with PVY antiserum(1/1000 dilution)

1, 2: Purified samples

3: Control +

4: Control -

\section{Results}

The percent age of the collected samples from different fields which reacted positively in DASELISA with PVY polyclonal antiserum was 59\%. Host range studies showed that pepper isolate caused vein clearing and yellowing on C.annuum

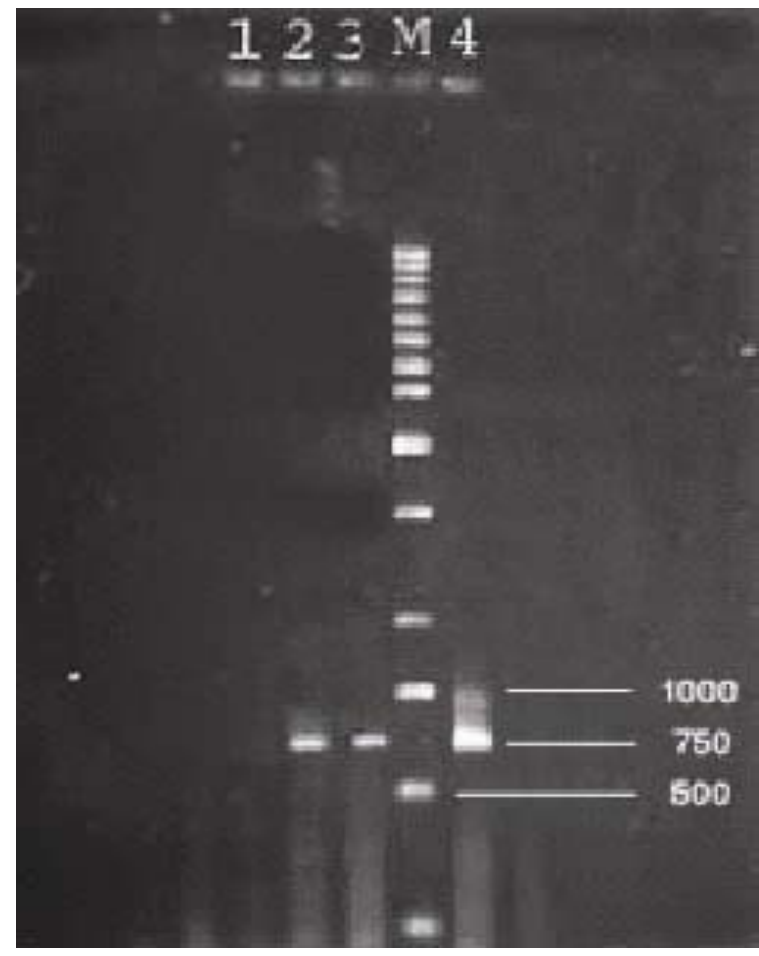

Fig. 8: IC-RT-PCR with PVYO primer 1: Healthy samples 2, 3, 4: infective samples, M: Marker

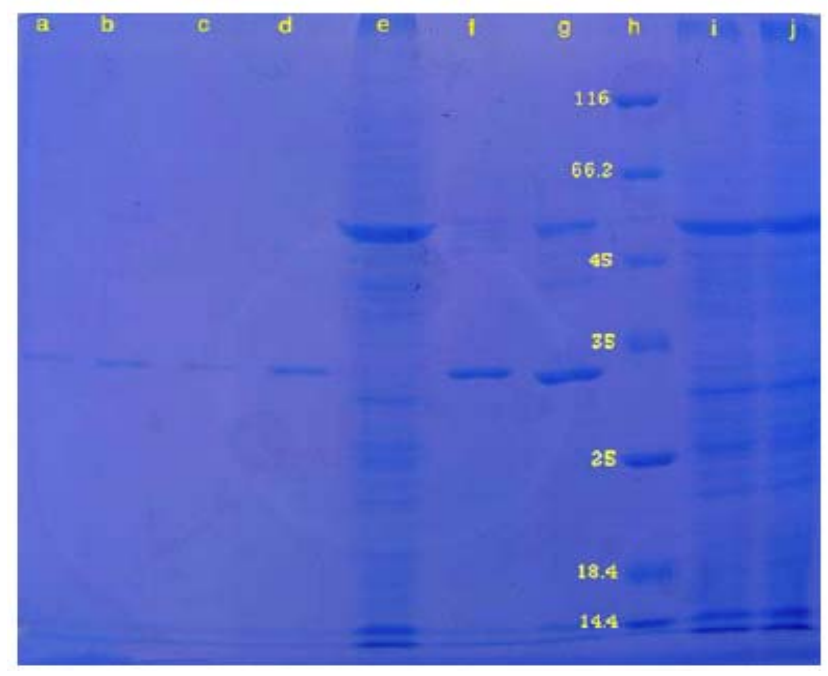

Fig. 5: a,b,c,d: complete purified samples

e: healthy samples

$\mathrm{f}, \mathrm{g}$ : not complete purified samples h:marker

i,j: plant samples

(Figure3), vein banding and mosaic on D.metel (Figure4), mosaic on N.tabacum cv.White Burley (Fig. 1) and N.rustica (Fig. 2) but didn't show any symptoms on P.floridana, C.amar-anticolor, C.quinoa and Solanum tuberosum.

After physical purification the A260/280 absorbance ratio was estimated. The A260/280 absorbance ratio of the isolate was 1.50 for purified virus preparation from N.tabacum cv. White Burley. SDS-PAGE of the coat protein extracted from purified virus prepara-tion gave bands at position of about $34 \mathrm{KDal}$ (Fig. 5) and Western Blotting confirmed it as the PVY coat protein (Fig. 6).

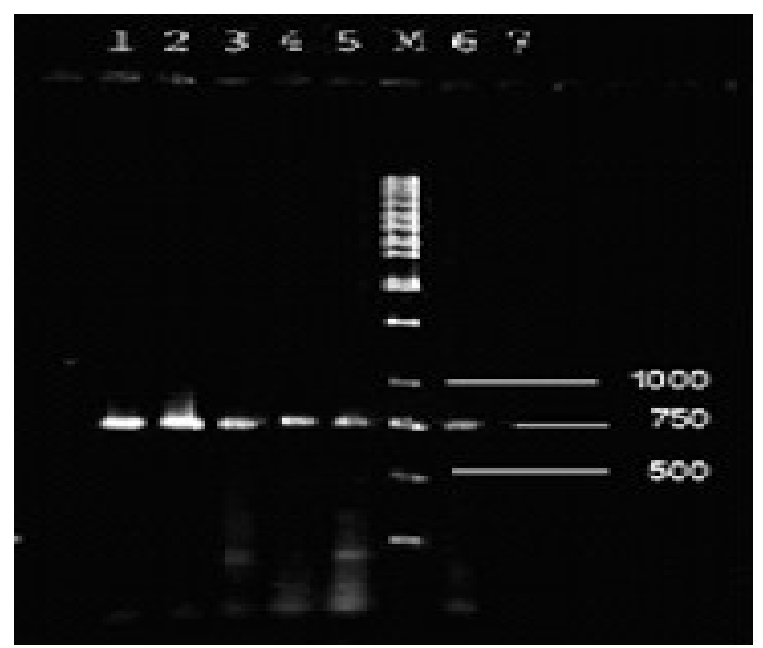

Fig. 7: IC-RT-PCR with PVY primer1-6: infective samples 7 : healthy sample $M$ : Marker 
The fragment of about 750 bp obtained after ICRT-PCR by using specific primer pair of coat protein region of PVY(Fig. 7). Also for PVY strain detection primer pair o-8687F and o-9995R were used and the length of the amplified fragment was about $680 \mathrm{bp}$ which determined this isolate as $\mathrm{PVY}^{\mathrm{O}}$ but phylogenetic analysis of PVY isolates shows that pepper-PVY isolates from Tehran pepper fields has highest percentage of similarity with the non potato isolates :LYE84.2 (95\%) and SON41 (90\%).

\section{Discussion}

This is the first report of PVY incidence in Iran pepper fields. We present a biological, serological and molecular characterization of pepper isolate of PVY,

The symptomology results described above showed that typical pepper-PVY isolates were distinguished from potato isolates by host range (8). After phylogenetic analysis we noticed that pepper isolate has high similarity with LYE 84.2 strain that was isolated from tomato (6) and with SON41 strain witch was isolated from $C$. annuum (5).

For this reason pepper infecting isolates could be classified within the $\mathrm{PVY}^{\mathrm{NP}}$ group that expanding earlier suggestions made by Romero et al. (10).

\section{References}

1. Boonham, N., K. Walsh, S. Preston and J. North; 2002; The detection of tuber necrotic isolates of Potato Virus $\mathrm{Y}$, and the occurate discrimination of PVYO, PVYN and PVYC strains using RT-PCR. Journal of virological methods 102:103-112.

2. Clark, M. F. and A. N. Adams; 1977; Characteristic of the microplate method of enzyme-linked immune-sorbent assay for the detection of plant viruses. J. Gen. Virol 34:475-483.

3. DeBokx, J.A. and H. Huttinga; 1981; Potato Virus Y .CMI/AAB. Description of plant viruses $242: 1-12$

4. Fanigliulo, A., S. Comes, R. Pacena, B. Harrach, D. Martin, and A. Crescenzi; 2005; Characterisation of potato virus Ynnp strain inducin $g$ veinal necrosis in pepper; a naturally occurring recombinant strain of PVY. Arch Virol 150: 709-720.
5. Glais, L., C. Kerlan, M. Tribodet, S. AstierManifacier and C. Robaglia; 1996; Molecular characterization of Potato Virus Y isolated by PCR-RFLP. Eur. J. Plant Pathol. 102:655-662.

6. Gebré-Selassié, K., G. Marchoux, B. Delecolle, and E. Pochard; 1985; Variabilité naturelle des souches du virus $Y$ de la pomme de terre dans les cultures de piment du sud-est de la France. Caractérisation et classification en pathotypes. Agronomie 5:621-630.

7. Legnani, R.; 1995; Analyse, comparaison et exploitation des résistances au virus $\mathrm{Y}$ de la pomme de terre (PVY) et au tobacco etch virus (TEV) chez la tomate. PhD thesis, University of Montpellier II, France.

8. Leiser, R. M. and J. Richter; 1979; Arch. Phytopath. PflSchutz. 14:337.

9. Posada, D. and K. A. Crandall; 2001; Evaluation of methods for detecting recombination from DNA sequences: Simulations, Proc Nah Acad Sci.USA 98:13757-13762.

10. Romero, A., B. Blanco-Urgoiti, M. J. Soto, A. Fereres and F. Ponz; 2001; Characterization of typical pepper-isolates of PVY reveals multiple pathotypes within a single genetic strain. Virus Research 79:71-80.

11. Shukla, D. D., C. W. Ward and A. A. Brunt; 1994; the Potyviridae. CAB International, Wallingford, UK. 